\title{
PENGKAJIAN PENDIDIKAN TINGKAT SMP DAERAH PERBATASAN DI KABUPATEN BENGKAYANG PROVINSI KALIMANTAN BARAT
}

Oleh:

Eusabinus Bunau ${ }^{1}$, Laurensius Salem ${ }^{2}$, Clarry $\mathrm{Sada}^{3}$, Albert Rufinus $^{4}$

Abstrak: Data untuk penelitian ini diperoleh dari SMPN 1 Suti Semarang, SMPN 1 Sangau Ledo, SMPN 2 Sanggau Ledo, SMPN 3 Sanggau Ledo, SMPN 1 Seluas, SMPN 2 Seluas, SMPN 3 Seluas, SMPN 1 Siding, dan SMPN 1 Jagoi Babang Kabupaten Bengkayang. Teknik yang dipergunakan untuk pengambilan data adalah teknik survey. Alat pengumpul data terdiri dari questionnaire terbuka dan tertutup, dan format isian data untuk mengumpulkan data angkaangka, dan pedoman wawancara untuk menghimpun informasi yang bersifat kualitatif dari sumber data seperti Kepala Dinas, Kepala Cabang Dinas Pendidikan, perwakilan Komite Sekolah, perwakilan orang tua dan perwakilan siswa. Data diolah dengan menggunakan metode deskriptif. Masalah yang dikemukakan dalam penelitian ini adalah gambaran umum tentang implementasi Kurikulum KTSP, TV Edukasi, Bahan Ajar, Prasarana gedung dan sumber daya guru, dan Evaluasi (UAN). Temuan penelitian menunjukkan bahwa KTSP belum sepenuhnya diimplementasikan berdasarkan standar kompetensi, kompetensi dasar, indikator dan tujuan pembelajaran yang benar menurut kaedah KTSP; TV Edukasi hanya berbentuk fisiknya saja, belum berfungsi sebagai media dan sarana belajar; Bahan ajar untuk pelajaran yang diUANkan belum terpenuhi untuk semua siswa; Prasarana belajar seperti laboratorium dan perpustakaan masih sangat memprihatinkan; Sumber daya guru masih sangat jauh dari memadai berdasarkan kualifikasi/tingkat pendidikan; dan Selisih

${ }^{1}$ Eusabinus Bunau adalah dosen jurusan PBS FKIP Untan

${ }^{2}$ Laurensius Salem adalah dosen jurusan PBS FKIP Untan

${ }^{3}$ Clarry Sada adalah dosen jurusan PBS FKIP Untan

${ }^{4}$ Albert Rufinus dosen jurusan PBS FKIP Untan 
antara nilai tertinggi dan terendah untuk setiap mata pelajaran yang diUAN-kan masih sangat besar.

Kata Kunci: Pendidikan Tingkat Sekolah Menengah Pertama dan Daerah Perbatasan.

\section{Latar Belakang Masalah Penelitian}

Kalimantan Barat adalah zona Indonesia yang langsung berbatasan dengan negara tentangga, yaitu Malaysia. Setidaknya ada 5 kabupaten yang berbatasan langsung dengan Malaysia yaitu Kabupaten Sambas, Bengkayang, Sanggau, Sintang dan Kapuas Hulu. Perbedaan kondisi daerah yang ada di sekitar perbatasan sangat terkait dengan pembangunan pendidikan sehingga aspek-aspek lain ikut berdampak.

Penelitian pendidikan perbatasan sangat penting untuk mengetahui gambaran umum mengenai implementasi kurikulum KTSP, sarana dan prasarana, TV edukasi, dan Evaluasi (UAN), khususnya di daerah perbatasan di kabupaten Bengkayang. Penerapan progran TV edukasi merupakan perkembangan baru dalam penyelenggaraan kegiatan belajar di kelas. Bahan/buku ajar sangat penting sehingga perlu diperhatikan. Tanpa bahan ajar murid mengalami kesulitan untuk mengikuti proses belajar dan mengajar. Bahan ajar menjadi sumber belajar yang penting karena bahan ajar akan sangat membantu proses belajar di rumah.

Semua komponen yang terkait dengan proses belajar bergantung dari sumber daya manusia yang bergerak dalam bidang pendidikan. Sebab sebaik apapun kurikulum, sarana dan prasarana dan bahan ajar, jika sumber daya manusianya kurang maka akan mendatangkan hasil yang kurang pula.

Masalah yang dikemukakan untuk penelitian ini adalah implementasi Kurikulum KTSP, TV Edukasi, Bahan Ajar, Prasarana gedung dan sumber daya guru, dan Evaluasi (UAN). Penelitian ini dimaksudkan untuk memberikan deskripsi atau gambaran umum mengenai sumber daya pendidikan tingkat SMP di daerah perbatasan di Kabupaten Bengkayang dan hasil penelitian dapat menjadi dasar untuk menyusun rencana tindak lanjut melalui program-program di bidang pendidikan di Kabupaten Bengkayang. 


\section{Data Hasil Penelitian}

\section{a. Kurikulum KTSP}

Kurikulum KTSP, bagi banyak guru, masih merupakan hal yang baru (dan membingungkan). Dari 73 guru SMP di kecamatan perbatasan di kabupaten Bengkayang yang menjadi responden penelitian ini, sebanyak 51 $(69,86 \%)$ responden tidak dapat membedakan antara kurikulum dan silabus. Sebanyak 63 (86,30\%) responden tidak mengetahui secara tepat komponenkomponen yang ada dalam KTSP. Sebanyak 67 (91,78\%) responden tidak mengetahui bagaimana mencocokkan materi bahan ajar dari bahan ajar dengan keterampilan/skill yang akan diajarkan ketika mereka menyusun RPP.

Sebanyak 67 (91,78\%) responden tidak mengetahui bagaimana mencocokkan materi bahan ajar dari bahan ajar dengan indikator yang disarankan untuk dipenuhi ketika mereka menyusun RPP. Sebanyak 67 (91,78\%) responden tidak mengetahui bagaimana mencocokkan materi bahan ajar dari bahan ajar dengan tujuan pembelajaran yang hendak dicapai ketika mereka menyusun RPP. Sebanyak 69 (94,52\%) responden tidak dapat membuat soal untuk evaluasi pada akhir pembelajaran dengan baik dan benar. Terakhir, sebanyak 69 (94,52\%) responden tidak dapat membuat rubrik penilaian untuk materi yang dievaluasi pada akhir pembelajaran.

\section{b. TV Edukasi}

TVE adalah media pembelajaran yang diharapkan menjadi media pendukung selain Proses Belajar dan Mengajar (PBM) dan buku/bahan ajar di ruang kelas. Akses program TVE hanya dapat diperoleh melalui siaran televisi. Peralatan yang menjadi syarat mutlak agar siaran dapat ditangkap, selain pesawat $\mathrm{TV}$, adalah parabola yang dilengkapi dengan motor penggerak. Genset atau mesin listrik generator juga harus disediakan untuk mengantisipasi listrik mati ketika siaran sedang ditangkap.

Selain itu, TVE harus juga dilengkapi DVD/CD player jika program TVE disertai dengan material rekaman yang diproduksi oleh PUSTEKKOM. Tujuan pengadaan material rekaman adalah supaya program TVE di kelas (di ruang khusus atau laboratorium) dapat diselenggarakan berdasarkan jadwal yang dibuat di sekolah, tanpa harus menyesuaikan jam tayang melalui siaran 
TV Edukasi yang kebanyakan berlangsung pada siang dan malam hari (khususnya untuk mata pelajaran IPA, matematika, bahasa Inggris dan bahasa Indonesia).

Tidak semua SMPN di daerah pedalaman atau wilayah perbatasan di kabupaten Bengkayang telah memiliki pesawat TV dan program TV Edukasi. Dari 8 SMP yang menjadi lokasi penelitian ini, hanya baru 5 SMP saja yang telah memiliki pesawat TV dan program TV Edukasi ini. Sedangkan 3 SMP lainnya, yakni SMPN 2 Seluas, SMPN 3 Seluas dan SMPN 1 Suti Semarang tidak/belum memiliki pesawat TV dan Program TV Edukasi ini.

Dari 5 SMP yang telah memiliki pesawat TV dan Program TV Edukasi di kecamatan daerah perbatasan kabupaten Bengkayang, tidak ada satu SMP pun yang melaksanakan PBM dengan media dan sarana TV Edukasi ini. Alasannya adalah bahwa program TV Edukasi ini hanyalah berupa pesawat TV secara fisik belaka. Bahkan ada komponen di dalam pesawat TV yang ditukar oleh pelaksana tender. TV tidak dilengkapi parabola, tidak dilengkapi dengan CD/DVD player, tidak dilengkapi dengan genset, dan hanya ada 1 SMP saja yang dilengkapi dengan material rekaman tetapi tidak pernah dipergunakan untuk PBM.

\section{c. Bahan/buku Ajar}

Seluruh sesponden dan informan yang berasal dari unsur kepala dinas, kepala cabang dinas, kepala sekolah, guru, perwakilan komite sekolah, perwakilan orang tua siswa dan perwakilan siswa menyatakan bahwa bahan/buku ajar belum tersedia untuk semua mata pelajaran. Yang belum tersedia meliputi buku-buku pelajaran PPKN, agama, KTK, buku-buku penunjang muatan lokal (Mulok) dan kamus.

Sebagian bahan/buku ajar yang disimpan di perpustakaan dipinjamkan kepada siswa pada jam pelajaran dan dikembalikan ke perpustakaan setelah selesai jam pelajaran. Bahkan bahan/buku ajar seperti Matematika, IPA, IPS, dan bahasa Inggris dipinjamkan kepada sebagian besar siswa selama 1 tahun pelajaran dan dikembalikan ke sekolah (perpustakaan) setelah tahun pelajaran berakhir.

Untuk perpustakaan, bahan/buku ajar bersumber (diadakan) dari pemerintah dan hanya untuk siswa yang jumlahnya terbatas, buku-buku 
pelajaran tertentu mereka beli sendiri dari toko buku. Selain itu, bahan/buku ajar yang umumnya dibeli siswa antara lain adalah LKS dan kamus. Mekanisme pengadaan buku yang diselenggarakan oleh sekolah (karena rekomendasi kepala sekolah dan oknum dari dinas atau cabang dinas) menyebabkan munculnya praktik kolusi pengadaan buku menjadi penjualan buku yang bersifat memaksa dan memberatkan orang tua siswa. Hampir $80 \%$ bahan/buku ajar yang pengadaannya dilakukan melalui mekanisme penjualan ini berasal dari penerbit tertentu yang bersifat monopoli.

\section{d. Prasarana dan Sumber Daya Guru}

Di SMPN 1 Suti Semarang, kelas 7 memiliki sebanyak 86 siswa; kelas 8 sebanyak 49 siswa; kelas 9 sebanyak 36 siswa; 2 siswa tidak naik kelas 8 dan 1 siswa tidak naik kelas 9; jumlah SD input sebanyak 6 SD; terdapat hanya 1 perpustakaan sedangkan lab IPA, bahasa dan IPS tidak ada; dan hanya terdapat 1 lapangan volley sebagai fasilitas olah raga. Kegiatan ekstrakurikuler yang diselenggarakan meliputi pramuka, sepak bola dan volley ball. Jumlah total guru sebanyak 13 orang, terdiri dari 5 PNS, 1 guru berpendidikan SLTA/sederajat, 1 D2, 3 D3 dan 8 S-1.

Di SMPN 1 Sanggau Ledo, kelas 7 memiliki sebanyak 152 siswa; kelas 8 sebanyak 136 siswa; kelas 9 sebanyak 126 siswa; 11 siswa tidak naik kelas 8 dan 8 siswa tidak naik kelas 9; jumlah SD input sebanyak 12 SD; terdapat hanya 1 lab IPA dan 1 perpustakaan sedangkan lab bahasa dan IPS tidak ada; dan hanya terdapat 1 lapangan bola dan 1 lapangan volley sebagai fasilitas olah raga. Kegiatan ekstrakurikuler yang diselenggarakan meliputi pramuka, pencak silat, sepak bola, volley, sepak takraw, tennis meja dan vokal group. Jumlah total guru sebanyak 30 orang, terdiri dari 22 PNS, 9 guru berpendidikan SLTA/sederajat, 2 D1, 3 D2, 4 D3 dan 16 guru berkualifikasi S-1.

Di SMPN 2 Sanggau Ledo, kelas 7 memiliki sebanyak 127; kelas 8 sebanyak 140 siswa; kelas 9 sebanyak 113 siswa; 2 siswa tidak naik kelas 8 dan 2 siswa tidak naik kelas 9; jumlah SD input sebanyak 12 SD; terdapat hanya 1 lab IPA dan 1 perpustakaan sedangkan lab bahasa dan IPS tidak ada; dan tidak ada data mengenai fasilitas olah raga. Tidak ada data mengenai kegiatan ektrakurikuler yang diselenggarakan di sekolah. Begitu juga halnya tidak ada data mengenai jumlah, tingkat pendidikan dan status guru. 
Di SMPN 3 Sanggau Ledo, kelas 7 memiliki sebanyak 30 siswa; kelas 8 sebanyak 41 siswa; kelas 9 sebanyak 15 siswa. Jumlah SD input sebanyak $5 \mathrm{SD}$; terdapat hanya 1 perpustakaan dan tidak ada lab IPA, lab bahasa dan IPS; dan tidak terdapat satupun lapangan bola dan lapangan volley sebagai fasilitas olah raga. Kegiatan ekstrakurikuler yang diselenggarakan di sekolah adalah pramuka. Jumlah total guru sebanyak 10 orang, terdiri dari 7 PNS, 2 guru berpendidikan SLTA/sederajat, dan tidak ada data mengenai pendidikan guru untuk tingkat D1, D2, D3 dan S-1.

Di SMPN 1 Seluas, kelas 7 memiliki sebanyak 135 siswa; kelas 8 sebanyak 115 siswa; kelas 9 sebanyak 96 siswa; 21 siswa tidak naik kelas 8 dan 16 siswa tidak naik kelas 9; tidak ada informasi mengenai jumlah SD input; terdapat hanya 1 lab IPA dan 1 perpustakaan sedangkan lab bahasa dan IPS tidak ada; dan hanya terdapat 1 lapangan volley sebagai fasilitas olah raga. Kegiatan ekstrakurikuler yang diselenggarakan meliputi pramuka, PMR dan KIK. Jumlah total guru sebanyak 16 orang, terdiri dari 9 PNS dan 7 nonPNS, 0 guru berpendidikan SLTA/sederajat, 3 D1, 3 D2, 2 D3 dan 8 S-1.

Di SMPN 2 Seluas, kelas 7 memiliki sebanyak 27 siswa; kelas 8 sebanyak 18 siswa; kelas 9 sebanyak 21 siswa; 0 siswa tidak naik kelas 8 dan 0 siswa tidak naik kelas 9; jumlah SD input sebanyak 4 SD; tidak terdapat satupun laboratorium dan 1 perpustakaan; dan hanya terdapat 1 lapangan lapangan volley sebagai fasilitas olah raga. Kegiatan ekstrakurikuler yang diselenggarakan meliputi pramuka dan bola volley. Jumlah total guru sebanyak 7 orang, terdiri dari 3 PNS dan 4 non-PNS, 2 guru berpendidikan SLTA/sederajat, 1 D2, 1 D3 dan 2 S-1.

Di SMPN 3 Sanggau Ledo, kelas 7 memiliki sebanyak 74 siswa; kelas 8 sebanyak 62 siswa; kelas 9 sebanyak 52 siswa; 4 siswa tidak naik kelas 8 dan 12 siswa tidak naik kelas 9; tidak diperoleh informasi mengenai jumlah SD input; tidak terdapat satupun laboratorium dan perpustakaan; dan hanya terdapat 1 lapangan lapangan volley sebagai fasilitas olah raga. Kegiatan ekstrakurikuler yang diselenggarakan adalah pramuka. Jumlah total guru sebanyak 14 orang, terdiri dari 7 PNS dan 7 non-PNS, 1 guru berpendidikan SLTA/sederajat, 1 D2, 3 D3 dan 9 S-1.

SMPN 2 Jagoi Babang merupakan SMPN baru dan menerima siswa kelas 7 untuk pertama kalinya pada tahun ini. Di SMPN 2 Jagoi Babang, kelas 7 memiliki sebanyak 21 siswa dan 1 kelas (rombongan belajar). Tidak 
ada data mengenai SD input/asal siswa dan belum memiliki fasilitas laboratorium dan fasilitas olah raga serta belum memiliki kegiatan ekstra kurikuler. Jumlah total guru sebanyak 4 orang, yang semuanya merupakan guru bantu atau tidak ada satupun guru tetap PNS. Dari 4 orang guru tidak tetap tersebut 3 guru berpendidikan SLTA/sederajat dan 1 orang guru berpendidikan D1.

Di SMPN 1 Jagoi Babang, kelas 7 memiliki sebanyak 54 siswa; kelas 8 sebanyak 61 siswa; kelas 9 sebanyak 45 siswa; 2 siswa tidak naik kelas 8 dan 2 siswa tidak naik kelas 9; jumlah SD input sebanyak $6 \mathrm{SD}$; tidak terdapat satupun laboratorium dan 1 perpustakaan; dan hanya terdapat 1 lapangan lapangan volley sebagai fasilitas olah raga. Kegiatan ekstrakurikuler yang diselenggarakan meliputi pramuka dan Orkes (olah raga kesehatan). Jumlah total guru sebanyak 17 orang, terdiri dari 5 PNS dan 12 non-PNS, 1 guru berpendidikan SLTA/sederajat, 2 D2, 3 D3 dan 11 S-1.

\section{e. Evaluasi (UAN)}

Di SMPN 1 Suti Semarang, nilai Bahasa Indonesia, tertinggi 9,40, terendah 3,80 dan rata-rata 6,50; Matematika, tertinggi 8,67, terendah 1,67 dan rata-rata 4,78; Bahasa Inggris, tertinggi 8,40, terendah 2,40 dan rata-rata 5,20; dan persentase kelulusan Bahasa Indonesia 96,83\%, Matematika $85,71 \%$ dan Bahasa Inggris 25,71\%.

Di SMPN 1 Sanggau Ledo, nilai Bahasa Indonesia, tertinggi 9,00, terendah 4,60 dan rata-rata 7,04; Matematika, tertinggi 9,67, terendah 4,00 dan rata-rata 6,77; Bahasa Inggris, tertinggi 8,00, terendah 4,00 dan rata-rata 5,27; dan persentase kelulusan Bahasa Indonesia 70,40\%, Matematika $67,70 \%$ dan Bahasa Inggris 52,70\%.

SMPN 2 Sanggau Ledo merupakan SMPN yang sudah cukup lama berdiri, yaitu setelah SMPN 1 Sanggau Ledo. Sayangnya tidak terdapat data mengenai evaluasi (atau kelulusan mata pelajaran UAN) sehingga sulit untuk membuat analisis atau deskripsi mengenai keberhasilan atau kegagalan UAN.

Di SMPN 1 Seluas, nilai Bahasa Indonesia, tertinggi 8,80, terendah 3,20 dan rata-rata 6,19; Matematika, tertinggi 9,33, terendah 1,33 dan ratarata 4,40; Bahasa Inggris, tertinggi 8,20, terendah 2,40 dan rata-rata 4,62; dan persentase kelulusan Bahasa Indonesia 80,76\%, Matematika 58,63\% dan Bahasa Inggris 56,33\%. 
Di SMPN 2 Seluas, nilai Bahasa Indonesia, tertinggi 7,20, terendah 2,80 dan rata-rata 5,49; Matematika, tertinggi 6,67, terendah 1,33 dan ratarata 3,83; Bahasa Inggris, tertinggi 6,80, terendah 3,00 dan rata-rata 4,29; dan persentase kelulusan Bahasa Indonesia 91,30\%, Matematika 43,48\% dan Bahasa Inggris 34,78\%.

Di SMPN 3 Seluas, nilai Bahasa Indonesia, tertinggi 8,00, terendah 2,80 dan rata-rata 5,05; Matematika, tertinggi 8,00 , terendah 1,33 dan ratarata 4,33; Bahasa Inggris, tertinggi 8,20, terendah 2,40 dan rata-rata 4,62; dan persentase kelulusan Bahasa Indonesia 65\%, Matematika 18\% dan Bahasa Inggris $16 \%$.

Di SMPN 1 Jagoi Babang, nilai Bahasa Indonesia, tertinggi 9,20, terendah 3,20 dan rata-rata 5,80; Matematika, tertinggi 7,67, terendah 1,67 dan rata-rata 4,69; Bahasa Inggris, tertinggi 8,20, terendah 2,40 dan rata-rata 4,62; dan persentase kelulusan Bahasa Indonesia 90,40\%, Matematika $63,64 \%$ dan Bahasa Inggris 56,82\%.

\section{Pembahasan Hasil Penelitian}

KTSP adalah kurikulum operasional yang disusun oleh dan dilaksanakan di masing-masing satuan pendidikan. KTSP terdiri dari tujuan pendidikan tingkat satuan pendidikan, struktur dan muatan kurikulum tingkat satuan pendidikan, kalender pendidikan, dan silabus. Kurikulum adalah seperangkat rencana dan pengaturan mengenai tujuan, isi, dan bahan pelajaran serta cara yang digunakan sebagai pedoman penyelenggaraan kegiatan pembelajaran untuk mencapai tujuan pendidikan tertentu.

Silabus adalah rencana pembelajaran pada suatu dan/atau kelompok mata pelajaran/tema tertentu yang mencakup standar kompetensi, kompetensi dasar, materi pokok/pembelajaran, kegiatan pembelajaran, indikator, penilaian, alokasi waktu, dan sumber/bahan/alat belajar. Silabus merupakan penjabaran standar kompetensi dan kompetensi dasar ke dalam materi pokok/pembelajaran, kegiatan pembelajaran, dan indikator pencapaian kompetensi untuk penilaian.

Berdasarkan data hasil penelitian, khususnya aspek KTSP, dapat diinterpretasikan bahwa sebagian besar guru yang menjadi responden penelitian belum sepenuhnya dapat mengimplementasikan KTSP berdasarkan standar kompetensi, kompetensi dasar, indikator dan tujuan pembelajaran 
yang benar menurut kaedah KTSP. Kesulitan mengimplementasikan KTSP dimulai dari kesulitan mengelaborasi PBM berdasarkan standar kompetensi, kompetensi dasar, indikator dan tujuan pembelajaran yang hendak dicapai.

KTSP haruslah kelihatan dan terukur pada RPP yang dipergunakan guru pada saat PBM. Tidak dapat membuat soal untuk evaluasi pada akhir pembelajaran dengan baik dan benar; dan tidak dapat membuat rubrik penilaian untuk materi yang dievaluasi pada akhir pembelajaran merupakan bukti yang kuat bahwa implementasi KTSP memang masih jauh dari harapan.

TV Edukasi hanya berbentuk fisiknya saja, belum berfungsi sebagai media dan sarana belajar. Program TV Edukasi sebagai media, sarana dan penunjang PBM ini tidak dapat dilaksanakan karena hanya berupa pesawat TV secara fisik belaka. TV tidak dilengkapi parabola, tidak dilengkapi dengan CD/DVD player, tidak dilengkapi dengan genset. Meskipun dilengkapi dengan material rekaman tetapi material rekaman tidak pernah dipergunakan untuk PBM.

Tidak semua bahan/buku ajar tersedia untuk semua pelajaran dan untuk semua siswa. Bahkan ada bahan/buku ajar untuk pelajaran yang diUANkan belum terpenuhi untuk semua siswa. Kondisi prasarana belajar seperti laboratorium dan perpustakaan masih sangat memprihatinkan. Kondisi sumber daya guru masih sangat jauh dari memadai berdasarkan kualifikasi/tingkat pendidikan. Sedangkan selisih antara nilai tertinggi dan terendah untuk setiap mata pelajaran yang diUANkan masih sangat besar.

\section{Kesimpulan dan saran}

KTSP belum sepenuhnya diimplementasikan berdasarkan standar kompetensi, kompetensi dasar, indikator dan tujuan pembelajaran yang benar menurut kaedah KTSP; TV Edukasi hanya berbentuk fisiknya saja, belum berfungsi sebagai media dan sarana belajar; Bahan ajar untuk pelajaran yang diUANkan belum terpenuhi untuk semua siswa; Prasarana belajar seperti laboratorium dan perpustakaan masih sangat memprihatinkan; Sumber daya guru masih sangat jauh dari memadai berdasarkan kualifikasi/tingkat pendidikan; dan Selisih antara nilai tertinggi dan terendah untuk setiap mata pelajaran yang diUANkan masih sangat besar. 
Disarankan kepada Dinas Kabupaten Bengkayang untuk mengevaluasi keterlaksanaan KTSP. Program TV Edukasi sebaiknya didesentralisasikan pengadaannya oleh PEMDA Kabupaten. Buku-buku paket dan LKS serta kamus bahasa Inggris disarankan untuk diadakan oleh pemerintah daerah, bukan oleh penjual buku yang datang ke sekolah. Kualifikasi sumber daya guru direkomendasikan untuk memperoleh perhatian yang sangat serius dari pemerintah daerah. Sekolah disarankan untuk minimal memiliki perpustakaan (gedung dan buku yang memadai) dan 2 laboratorium, yaitu IPA dan bahasa (untuk bahasa Inggris) serta fasilitas olah raga yang cukup untuk memenuhi kebutuhan non-cognitif dan pengembangan bakat siswa. Disarankan kepada sekolah dan pemerintah daerah untuk mencari strategi lain, misalnya melalui bimbingan belajar khusus pra-UAN, supaya rentang antara nilai tertinggi dan terendah tidak terlalu besar dan persentase kelulusan dapat ditingkatkan.

\section{Pustakaan Rujukan}

Amsyah, Zulkifli, 2003, Manajemen Kearsipan, Gramedia Pustaka Utama, Jakarta.

Bacal, Robert, 2002, Performance Management, diterjemahkan oleh Surya Dharma dan Yanuar Irawan, Kanisius, Yogyakarta.

Davis, Keith, dan Newstorm, John W, 1996, Perilaku dalam organisasi, edisi ke-7 jilid 2, diterjemahkan oleh Agus Dharma, Erlangga, Jakarta.

Gay, L. R. 1992. Educational Research: Competencies for Analysis and Application. Forth Edition. Singapore: MacMillan Publishing Company.

Hakim, Rusman, 2001, Cermin Kepemimpinan, Elexmedia Komputindo, Jakarta.

Maddux, Robert B, 2001, Team Building, diterjemahkan oleh Kristiyabudi, Erlangga, Jakarta.

Maister, David H, 1998, True Professionalism, diterjemahkan oleh Bernardus Hidayat, Gramedia Pustaka Utama, Jakarta.

Oetomo, Budi Sutedjo Dharma, 2002, Perencanaan dan Pembangunan Sistim Informasi, Andi Offset, Yogyakarta.

O’Leary, Elizabeth, 2002, Kepemimpinan, diterjemahkan oleh Deddy Jacobus, Andi Offset, Yogyakarta. 
Vockell, Edward. L and Asher, J. William. 1995. Educational Research. Second Edition. New Jersey: Prentice Hall Inc.

http://www.uwep.ac/pde/qualitativedata.html; Ellen Taylor-Powell and Marcus Renner, 2003; accessed on May 21, 2007, http://www.uwep.ac/pde/qualitativeanalysis.html; Ellen Taylor-Powell and Sara Steele, 2003; accessed on May 21, 2007, http://www.auckland.ac.nz/qualitativedata.html; Kaplan and Maxwell, 1994; accessed on May 20, 2007. http://www.auckland.ac.nz/qualitativeresearch.html; Michael D. Myers, 1997; accessed on May 20, 2007.

http://www.dikdasmen/ktsp; Direktorat Pendidikan Dasar dan Menengah/KTSP; accessed on May 19, 2007. Undang-Undang No. 20 Tahun 2003 tentang Sistem Pendidikan Nasional. Peraturan Pemerintah No. 19 Tahun 2006 Tentang Kurikulum Tingkat Satuan Pendidikan (KTSP). 